Logos Universality Mentality Education Novelty, Section:

Political Sciences and European Studies

ISSN: $2284-5992$ (print), ISSN: $2284-5992$ (electronic)

Covered in: CEEOL, Index Copernicus, Ideas RePeC, EconPapers, Socionet

\title{
APPROACHES IN THE POLITICAL SCIENCE TODAY
}

Ciprian IFTIMOAEI

DOI:

http://dx.doi.org/10.18662/lumenpses.2015.0301.01

Logos Universality Mentality Education Novelty, Section:

Political Sciences and European Studies, 2015, Volume III, Issue 1, pp: $7-10$

\author{
Published by: \\ Lumen Publishing House \\ On behalf of:
}

Lumen Research Center in Social and Humanistic Sciences 


\title{
Approaches in the Political Science Today
}

\section{Ciprian IFTIMOAEI ${ }^{1}$}

\begin{abstract}
In over 2,000 years of existence, approaches in political science evolved from philosophical and normative reflections on various forms of organization of the ancient world to contemporary interdisciplinary approaches based on refining concepts and theories accumulated over time and the use of complex research methodologies, own or borrowed from related fields of studies such as sociology, political psychology, econometrics, advanced statistics. Although quantitative approaches prevails in contemporary research, does not lack political philosophy studies, theoretical and ideological approaches, inspired by everyday realities and empirical research results.
\end{abstract}

Keywords: political science, political philosophy, political theory, ideology.

${ }^{1}$ Post-PhD Researcher, „Al.I. Cuza” University of Iasi, ciprian.iftimoaei@gmail.com.

Iftimoaie, C. (2015). Approaches in the Political Science Today. Logos Universality Mentality Education Novelty, Section: Political Sciences and European Studies, III(1), 7-10. Doi: http://dx.doi.org/10.18662/lumenpses.2015.0301.01 
Political science was born in ancient Greece with the works of Plato (428-348 BC.) and Aristotle (384-322 BC.). The works of these classics of political science is intertwined philosophical and normative reflections about political statehood, forms of political organization and performance optimization. Plato based his political reflection from the postulation of ideal forms of political organization seeking objectivation in the concrete reality. Unlike his master, Aristotle was an empiricist, starting from the study of politics viewed in concrete forms of organization (constitutions) and continuing with the analysis and classification of them in order to produce functional types.

From the ancient Greeks up to modern era, political science has progressed shy. In the Middle Ages, political reflection brings together philosophical, moral and religious considerations on human nature analyzed in relation to governance issues. The doctrine of natural rights provides philosophical and normative landmarks that are assessed according to different forms of political organization and governance. The works of Thomas Aquinas (1225-1274) is an inflection point in medieval political thought, while Prince of Machiavelli (1469-1527) is the entering in the political modernity through a realistic approach of politics of his time.

Modernity brings substantial progress in the development of political science. Reflections of political philosophers like Hobbes, Locke, Montesquieu, Hume, Madison, Hamilton placed the origin of the state at the center, based on reflection of human nature, the legitimacy source of different forms of government, and the separation of powers. The relationship between state and citizen is founded on the idea of "social contract" theory that derived the theories of authority and legitimacy of power. The science of modern politics is seen as a philosophical and political theory, bringing together the history of political thought from Plato to Marx, conceptual clarifications of the political and ideological discourse as well as attempts to build formal models of political processes, inspired by theoretical and methodological acquisitions from political economy and sociology.

The professionalisation of political science was done in the second half of the Twentieth Century with the introduction of quantitative and qualitative methodologies to analyze data gathered from empirical research. Philosophical, legal and historical approaches are replaced by empirical studies regarding governments, forms of governance and the role played by governmental elites. A milestone in the professionalization of political

Iftimoaie, C. (2015). Approaches in the Political Science Today. Logos Universality Mentality Education Novelty, Section: Political Sciences and European Studies, III(1), 7-10. Doi: http://dx.doi.org/10.18662/lumenpses.2015.0301.01 
science is the emergence of the Chicago School (1920-1940), founded by Charles Merriam. The political scientist focused on applying concepts, theories, methods and research techniques from psychology and sociology. The increasing accumulation of empirical data on political processes imposed quantitative methodologies to the detriment of qualitative approaches. Merriam has been an institutional innovator by attaching its name to the creation of Social Science Research Committee in the University of Chicago, then establishing Social Science Research Council to provide research programs at national level for many American sociologists and political scientists. Lasswel Harrold (1902-1978) was one of the most prominent political scientists of the School of Chicago that explored "the psychological depths of politics." Later, Lasswell continued his research work at Yale University, where he inspired Dahl, Lindblom, and Lane in the development pf the department of political science.

After the Second World War, we can talk about a "maturation" of political science. "Behaviorist revolution" finally put his mark on everything that means in political science research. Psychological and sociological methodologies based on quantitative techniques in collection, analysis and interpretation of empirical data (questionnaires, interviews, sociometric tests, scales, psychosocial experiments, statistical processing) were known in all departments of political science in American universities and not only. "Cold War" has diversified sphere of political science concerns that enriched the sub-fields of international relations, political systems analysis, comparative politics, security studies, the study of international organizations, and diplomacy. Neither these sub-fields of political science were not excluded from quantification and interdisciplinary approaches (sociology, econometrics, macro-economics).

In the last decades of the twentieth century, it was developed the research of public policym, and the science of "new public management" appeared. It talks about "political economy of institutions" and the "economy of public policies". Important progress has been made in the study of political culture through the contributions of Gabriel Almond, Sidney Verba, Ronald Inglehart and Robert Putnam. The advance of the democratic theory was possible due to scientific contribution of Robert Dahl, Arend Lijphart, Giovanni Sartori, Juan Linz, Alfred Stepan, Larry Diamond, Phillipe Schimitter, Samuel Huntington. Political philosophy has not remained in place. On the contrary, this sub-field of political science was enriched by the philosophical and normative procurement of John Rawls

Iftimoaie, C. (2015). Approaches in the Political Science Today. Logos Universality Mentality Education Novelty, Section: Political Sciences and European Studies, III(1), 7-10. Doi: http://dx.doi.org/10.18662/lumenpses.2015.0301.01 
and Robert Nozick, inspired by the results of empirical researches. Political ideologies added the theory of feminism and environmentalism in its research portfolio. Political behavior is approached from a multidisciplinary perspective: political sociology, political psychology, economics, institutionalist approach. Rational choice theory perspective and juridical approaches in the study of political institutions have led to the development of a true science of administration at the confluence of political science, economics, constitutional and administrative law, public policy.

Inspired by the collapse of communist regimes in Central and Eastern Europe, but also by recent events such as the "Arab Spring", „Comparative Politics Today" brings together behavioral approaches (values, political culture and behaviors) and studies about democratization. Latest developments on the international scene have led to a revival of international relations, geopolitics and geostrategy, interdisciplinary approaches of terrorism as a global phenomenon of the XXI century. The Journal Logos, Universality, Mentality, Education, Novelty Section: Political Sciences and European Studies edited by LUMEN Publishing House of Iasi brings together a series of studies on current issues of political sciences from micro-politic (gender violence or abstinent alcoholics) to international relations and diplomacy (relations between Romania and Republic of Moldova under Russian regional influence, the role of Romanian-France relations in France's Eastern policy) that illustrate multi, trans and inter-disciplinarity in political sciences today.

\section{Biodata}

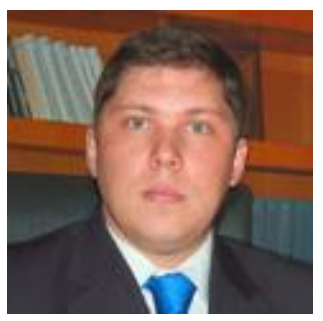

Ciprian IFTIMOAEI, $\mathrm{PhD}$ in Political Sciences, is Post-PhD Researcher in Project POSDRU/159/ 1.5.132400 and associate lecturer at the Department of Political Sciences, International Relations and European Studies, "Alexandru Ioan Cuza" University of Iasi; Member of the Society of Romanian Sociologists. Published books: Elitism. Theoretical and Ideological Contributions to the Study of Political Elites; Governmental Elites in PostCommunist Romania; Security, Democratic Consolidation and Good Governance. Romania within European Context.

Iftimoaie, C. (2015). Approaches in the Political Science Today. Logos Universality Mentality Education Novelty, Section: Political Sciences and European Studies, III(1), 7-10. Doi: http://dx.doi.org/10.18662/lumenpses.2015.0301.01 